\title{
BLOCKCHAIN TECHNOLOGY: IS IT AN ACCELERATOR FOR THE INCOMPLETE AGENDA OF FINANCIAL INCLUSION?
}

\author{
RAVIKUMAR $\mathbf{T}^{\mathbf{1}}$, MURUGAN $\mathbf{N}^{2} \&$ SUHASHINI $\mathbf{J}^{\mathbf{3}}$ \\ ${ }^{1}$ Associate Professor, CHRIST (Deemed to be University), Bangalore, India \\ ${ }^{2}$ Professor, PSNA College of Engineering and Technology, Dindigul, Tamil Nadu, India \\ ${ }^{3}$ Associate Professor, PSNA College of Engineering and Technology, Dindigul, Tamil Nadu, India
}

\begin{abstract}
The present research is undertaken with the objective of investigating whether Blockchain Technology (BT) drives and accelerates financial inclusion or not considering the existing state of financial inclusion. The research design of the study is descriptive in nature. The study is based on secondary information collected from The World Bank, National Association of Software and Service Companies (NASSCOM), Infosys limited, Cognizant Technology Solutions, Reserve Bank of India, Deloitte, International Financial Corporation, and Avasant Consulting. Blockchain Technology has the potential to be an alternative to the existing financial system. But, there is a long way to go to replace the existing financial system by BT because BT is in the nascent stage and replacement requires heavy capital investments. So, it is a rational idea to use BT to supplement the existing financial system. BT adoption in the financial system resolves almost all the problems presently encountered by the financial institutions to reach complete financial inclusion. BT creates digital identity, prompts near real time payment settlements, reduces transaction costs of the customers, reduces operational and administrative costs of the financial institutions, develops trust among the customers, and ensures access to financial services by everyone at anytime round the clock and round the year. This is a first such a detailed study that focuses on how does the features of Blockchain Technology accelerate the financial inclusion from the existing state of financial inclusion.
\end{abstract}

KEYWORDS: Blockchain Technology, Financial Inclusion, Accelerator, Trust, Financial Institutions

Received: Jun 08, 2020; Accepted: Jun 28, 2020; Published: Sep 09, 2020; Paper Id.: IJMPERDJUN20201126

\section{INTRODUCTION}

The financial sector has been facing a new paradigm that is fuelled by disruptive technologies and innovative financial products and services. This new paradigm has led to the emergence of Financial Technology (FinTech) businesses. FinTech businesses provide one or more financial products in an automated way using an online platform to the customers. Artificial Intelligence, Blockchain, Machine learning, and big data analytics are the technologies that make revolutions in the financial sector. Artificial intelligence and Machine learning have extensively been used in digital payments, digital lending, algorithm trading, wealth management, fraud detection, risk management, and financial cyber security. Blockchain Technology (BT) is used to facilitate remittances and international payments. BT is a decentralized data structure that allows one to generate digital ledgers that cannot be infringed and to share them. BT is a revolutionary technology that transfers the assets over the internet and makes the transactions more transparent, and efficient ${ }^{[1]}$. Blockchain Technology and Distributed Ledger Technology (DLT) are the two terms that are used interchangeably. But, there is a thin difference. Blockchain is a linearly connected chain of blocks and it is a special kind of DLT. On the other hand, DLT is a decentralized ledger 
that may or may not be a linear chain. Thus, all blockchains are DLT and all DLT platforms are not blockchains.

One of the objectives of central banks and formal financial institutions all over the world is achieving financial inclusion. Financial inclusion refers to "the provision of appropriate, affordable, and accessible financial products and services to vulnerable and low income individuals in a fair, sustainable, and transparent manner by the institutional player,"[2].

The financial institutions all over the world have been making efforts towards financial inclusion. Financial exclusion prevails all over the world and in India. 1.7 billion Adults across the world are still unbanked ${ }^{[3]}$. In India, still, $20.6 \%$ of the adults are unbanked and around 48 percent of bank accounts in India are inactive, and only seven percent of loans are issued by licensed financial institutions ${ }^{[4]}$. Thus, financial inclusion is an incomplete agenda for financial institutions and central banks.

Financial Inclusion (FI) has emerged as one of the prominent areas of study ${ }^{[5]}$. Among the various causes of poverty, the most important cause is financial exclusion. There are vast numbers of people financially excluded in the world $^{[6]}$. A well-developed financial system that reaches all people reduces costs, guides savings and investment decisions, and influences the long-run growth rates ${ }^{[7]}$ (Beck et al.2009). Financial exclusion leads to social exclusion and poverty ${ }^{[8]}$. The momentum in rural financial inclusion is barred due to higher operation costs and risks ${ }^{[9]}$. The benefits of financial inclusion didn't reach the low income people but reached higher income people ${ }^{[10]}$.

Blockchain technology has been indicated as the next big thing and the Blockchain can yield more benefits than the internet. Blockchain provides cheap, transparent, and secure transactions and thus, BT can be an alternative for the financial system. However, BT is to be used as a value addition to the existing development process ${ }^{[11]}$.

Even after a continued and concentrated efforts of various Central Banks and Governments, the financial institutions could achieve the policy objective of a hundred per cent financial inclusion because of inherent structural and operational barriers that prevail in the financial system. These inherent structural and operational barriers include the longer time required to open an account and to operate it, cost of maintaining the account, the safety of operations, privacy issues, larger investment on infrastructure, transparency, lack of trust, and a larger number of inactive accounts. The financial institutions and their prevailing technologies could tackle these problems.

A technology that has opened a world of new possibilities is Blockchain Technology ${ }^{[12]}$. Blockchain has the features to settle all the barriers faced by the financial institutions and the excluded people to reach a dream of a hundred percent financial inclusion in the world. Thus, blockchain has the potential to turn around the fortunes of the financial institutions in their endeavor towards financial inclusion.

\section{METHODS AND MATERIALS}

The research design of the study is descriptive in nature. The study is based on secondary information. The study intends to study the features of BT and its potential to enhance financial inclusion and thereby overall development of the society. The secondary information and data are collected from The World Bank, National Association of Software and Service Companies (NASSCOM), Infosys limited, Cognizant Technology Solutions, Reserve Bank of India, Deloitte, International Financial Corporation, and Avasant Consulting. 


\section{BLOCKCHAIN TECHNOLOGY AND ITS APPLICATIONS IN FINANCIAL SERVICES BUSINESS DOMAINS}

Blockchain is a linear DLT that distributes a common ledger to all the participants and it preserves and transmits data among the participants using blocks that are secured by cryptography in a digital chain. Blockchain Technology is a combination of technologies such as distributed ledger system, cryptography, peer-to-peer (P2P) networks, and consensus algorithms ${ }^{[13]}$. Blockchains employ cryptographic and algorithmic methods to record and synchronize data across a network in an immutable manner. Blockchain database allows peer-to-peer transactions without requiring a central authority ${ }^{[14]}$. Blockchain has both a medium of transactions and a means of recording $\mathrm{it}^{[15]}$. Illustration -1 depicts how is a blockchain transaction created?

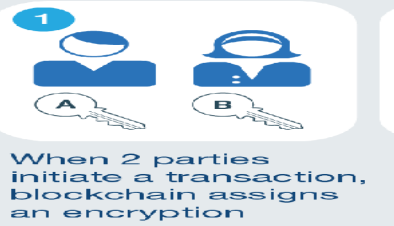

Source: McKinsey and Company ${ }^{[16]}$

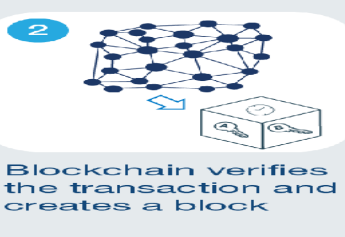

Blockohain verifies reates a block

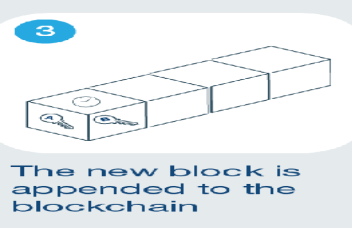

appended to the

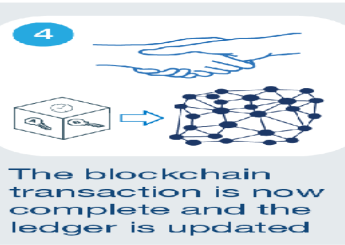

\section{Illustration: 1}

Table 1 summarizes the salient attributes of Blockchain Technology (BT) with the descriptions.

Table 1: Key Attributes of Blockchain Technology (BT)

\begin{tabular}{|c|c|}
\hline Attributes & Description \\
\hline Decentralization & BT has a decentralized global ledger of transactions that can digitally be accessed anywhere \\
\hline $\begin{array}{l}\text { Tamper-proof } \\
\text { Security }\end{array}$ & $\begin{array}{l}\text { BT has an electronic, secure, and time stamped transactions in the ledger which can't be } \\
\text { tampered }\end{array}$ \\
\hline Transparency & $\begin{array}{l}\text { Transactions carried out in BT are irrefutable as they are based on cryptography and peer-to- } \\
\text { peer network }\end{array}$ \\
\hline Immutability & Transactions in BT can't be stopped by a person or group of individuals without consensus \\
\hline Irreversibility & Transactions and information processed in BT can't be reversed or erased \\
\hline Precise & BT has a precise and verifiable record of each transaction \\
\hline Review & $\begin{array}{l}\text { Transactions done in BT can be reviewed on the basis of consensus of the majority of the } \\
\text { participants }\end{array}$ \\
\hline $\begin{array}{l}\text { Triple-entry } \\
\text { Accounting }\end{array}$ & $\begin{array}{l}\text { BT uses the Triple-Entry Accounting system. All accounting entries are cryptographically } \\
\text { sealed in BT by a third entry and it avoids manipulations and financial fraud in financial } \\
\text { statements. }\end{array}$ \\
\hline Privacy & BT records transactions without revealing the identity of parties and subject involved \\
\hline $\begin{array}{l}\text { Real Time } \\
\text { operations }\end{array}$ & Transactions are settled in BT within ten minutes. So, settlements are near real time \\
\hline $\begin{array}{l}\text { Transaction } \\
\text { specific rules }\end{array}$ & Transaction specific rules can be framed \\
\hline No intermediaries & BT doesn't require intermediaries to process the transactions \\
\hline
\end{tabular}

Vital components of BT operations are distributed ledger system, peer-to-peer network, cryptography, consensus mechanism, and rules of validity. BT applications can be in the areas of exchanges, payments, investments, financial data, trading finance, trade platforms, payroll and insurance, capital markets, retail and corporate banking, and micro transactions $^{[17]}$. Applications of BT in the financial services sector and in the business organizations are listed; 
- $\quad$ Since BT transactions cannot be breached and BT maintains the privacy of the parties involved in the transactions, financial institutions especially banks can adopt BT for their businesses. The financial institutions can even opt for permissioned BT wherein only authorized persons are allowed to take part in the BT network.

- Business organizations incorporate BT in their accounting system to avoid financial fraud and accounting manipulations as accounting entries are encrypted.

- Financial institutions construct smart contracts which are computer programs to replace the conventional contracts entered between the financial institutions and customers with regard to the lending of loans and advances. BT enables real time lending using smart contracts.

- $\quad$ BT is used to authorize the identities and documents in the financial service transactions

- $\quad$ BT is used in Wealth Management, Cash Reserve Management, Liquidity Management, Customer Acquisition and Management, and Intra Bank settlements in the commercial banks ${ }^{[18]}$.

- Debt servicing, insurance, and factoring services use BT to enhance their efficiency

- $\quad$ BT facilitates clearing and settlement in the capital market. For Instance, Hyperledger and Serica ${ }^{[19]}$.

- $\quad$ BT is used for trade execution and asset documentation in capital markets

- $\quad$ BT strengthens effective management of risks such as liquidity risk, systematic risk, operational risk, and counterparty risk.

- $\quad$ BT ensures regulatory transparency

In recent times, various countries' central banks, stock exchanges, Banking, Financial Services, and Insurance Industries (BFSI) have realized the potential of BT and unleashed their efforts to rational adoption of BT. 26 countries were investing in Blockchain ${ }^{[20]}$. This number has increased in the year 2019. In 2019, 52 countries involved in BT investment and in the development of BT standards and $50 \%$ of leading and enabling BT jurisdictions are located in Europe $^{[21]}$. Investment by venture capitalists in Blockchain initiatives in 2018 (USD 3.17B), exceeded the total value of the investment in the past 5 years from 2012-2017 (USD 2.56B) and Switzerland and Malta are the leading countries in the world in Blockchain Regulation Maturity ${ }^{[22]}$. India's approach towards BT is a cautious one. In 2018, the Finance Minister of India stated that India didn't recognize crypto-currencies as legal tender. Intially, the government of India (GOI) has not favored Virtual Currencies (VC), but, it favored the application of BT in the BFSI sector. As a result, the Reserve Bank of India published a blueprint for a common Blockchain based platform for the banking and financial services sector in January 2019. Ezyremit, a first Blockchain Company in Banking Financial Services and Insurance (BFSI) space emerged in April 2016 and ICICI bank executed India’s first banking transaction on Blockchain ${ }^{[23]}$.

\section{BLOCKCHAIN TECHNOLOGY AND FINANCIAL INCLUSION}

Financial inclusion is all about providing financial services such as savings, credit, remittance, and insurance services to the downtrodden and poor people and their businesses at the affordable cost. Although savings, credit, remittance, and insurance services form financial account, access to a savings account by a financially excluded individual makes a lot of difference in his life. If the financially excluded individual accesses the savings account in a bank, then he will get a debit card, credit card, loans of different kinds and insurance services provided the individual has adequate income. So, a savings 
account is a basic financial service that leads to financial inclusion. Despite having taken many initiatives towards financial inclusion, the central banks and the financial institutions across the countries struggle to provide financial services to everyone. 1.7 billion Adults are still unbanked all over the world including India. Financial inclusion initiatives could not be a complete success because of the structural and operational challenges of the existing financial system. So, new technology, new business approaches, and customer-centered financial products and services are needed to solve the problem of massive financial exclusion in the world. The financial institutions make use of a few technologies such as smart-phone, core banking solutions, and internet banking facilities in their businesses to overcome the limitations of having complete financial inclusion. But, these technologies facilitated financial inclusion and didn't help the financial institutions to reach the stage of complete financial inclusion. One technology which opens up new prospects to accelerate the dream of having the complete financial inclusion is Blockchain Technology. Blockchain Technology has the potential to drive and accelerate financial inclusion. The article sheds light on does BT drive and accelerate financial inclusion or not. The following points explain how does BT drive and accelerate financial inclusion?

\section{Digital Identity Creation}

Globally, there are 2.4 Billion people not having a digital identity to open a bank account ${ }^{[24]}$. As a result, they couldn't access formal financial institutions. The problem of digital identity can effectively be resolved by BT. BT creates digital identity using biometrics of facial expressions and voice recognition. The prospective users of BT need not have any physical identities such as passport, email, driving license, and so on. Identity theft in BT is impossible as BT is a distributed and tamperproof ledger. The digital identities created by BT can be used by the people to open a bank account and to access other financial services

\section{Regular Usage and Transactional Costs of Financial Services}

Mere having a bank account doesn't imply financial inclusion. Regular usage of bank account and other financial services ensures financial inclusion. 48 percent of bank accounts in India are inactive ${ }^{[25]}$. It is a serious concern. Regular usage of the bank account is hampered by higher transactional costs and delay in payment settlement especially international payment settlements. The problems of higher transactional costs and delays in settlements are effectively tackled in the Blockchain. In Blockchain, payment settlements can happen in near real time (within 10 minutes) even for an international settlement. Transfer fees in BT are determined as a percentage and not a flat rate per transaction. Further, no minimum ceiling is fixed in BT for a payment transaction. So, low transactional cost, faster settlement, and no minimum requirement may attract the customers of the bank to use the financial services regularly. Thus, BT promotes financial inclusion and makes financial inclusion as a strong financial goal.

\section{Lesser Infrastructure, Transactional and Administrative Costs to Financial Institutions (FIs)}

Financial institutions too need to bear certain costs such as branch management cost, customer relationship management cost, cost of compliances, the cost to be paid for the national and international payment system, and so on. National and international payment systems charge costs on payments from the financial institutions on the basis of the number of transactions. So, the FIs need to pay a fixed rate even for a small amount of transfer. As a result, the financial institutions are compelled to charge a higher transactional cost from the customers which hamper financial inclusion. But, when the financial institutions use BT, the financial institutions don't incur more costs on branch management and customer relation management. In fact, branches are not mandatory to do the banking business. Further, the financial institutions need not 
pay national and international payment systems as BT enabled payments don't require the intervention of national and international payment systems. Thus, BT reduces the costs of FIs. FIs can, in turn, reduce the costs of financial services offered by them which will attract unbanked and under-banked individuals towards formal financial systems.

\section{Trust}

Lack of trust in formal financial institutions by downtrodden and poor people is one of the prominent reasons for financial exclusion. Trust on formal financial institutions can be established and reaffirmed by using BT in the financial institutions because BT is an immutable, irreversible, and tamperproof distributed ledger. Further, BT enhances the security of the transactions multifold.

\section{Access to Marginalized People}

Blockchain Technology can create a digital identity for marginalized people such as migrants, and refugees. So, BT makes access to formal financial services by migrants and refugees a reality. Thus, Blockchain Technology enables more penetration of financial inclusion and paves a way for sustainable financial inclusion through digital identity creation, trust, lower transaction cost, lower administrative cost, near real time payment settlement, transparency, and secured transactions. Further, BT eliminates the need for intermediaries for the transactions which will make the customers access their fund round the clock and BT eliminates unnecessary documentation and complex procedures to undertake the transaction which makes the financial system a simple and accessible one.

However, Blockchain Technology adoption has certain challenges. First of all, BT is in an emerging stage and so, BT has its real life application problems. BT adoption requires changes in the existing technology which requires capital investments. The adoption of BT largely depends on the acceptance of BT by the users and financial institutions. Further, there is a larger amount of uncertainty over the regulations of BT especially in India by the competent authorities.

\section{DISCUSSIONS}

The financial institutions couldn't completely achieve financial inclusion despite making committed efforts and having the required technology in place. This incompletion is due to higher operational cost, higher transaction costs, lack of identity, low income, delay in payment settlements, lack of trust, privacy, and safety concerns that are embedded in the existing system. So, the existing financial system is to be disrupted to drive and accelerate the financial inclusion and the disruptor is "Blockchain Technology". Blockchain Technology is a linear distributed ledger system wherein the transactions are immutable, irrevocable, and tamperproof as the transactions are decentralized, encrypted using cryptography, peer to peer, consensus based, and rules based. In fact, Blockchain Technology has the potential to be an alternative to the existing financial system. But, there is a long way to go to replace the existing financial system by BT because BT is in the nascent stage and replacement requires heavy capital investments. So, it is a rational idea to use BT to supplement the existing financial system. BT adoption in the financial system resolves almost all the problems presently encountered by the financial institutions to reach complete financial inclusion. BT creates digital identity, prompts near real time payment settlements, reduces transaction costs of the customers, reduces operational and administrative costs of the financial institutions, develops trust among the customers, and ensures access to financial services by everyone at anytime round the clock and round the year. 


\section{CONCLUSIONS}

The ability to access formal financial services decides the economic life and economic well-being of individuals, households, and businesses. Till the year early 2000, there was not much concern among the central banks and the governments on bringing financially excluded people in to the formal financial system. Since 2005 onwards, the governments, the central banks, and the world financial institutions started to work towards financial inclusion. Numerous actions, policies, and objectives were considered for financial inclusion. But, the desired results were not received because of the traditional approach in respect of financial inclusion. So, the financial institutions and the central banks embraced technology enabled financial services to achieve complete financial inclusion. The technologies used include core banking, internet banking, smart-phone (Mobile) banking, and Unified Payment Interface. The technology facilitated approach towards financial inclusion yielded a significant improvement in the achievement of financial inclusion, especially in India. Between 2014 and 2017, 300 million people were brought in to the formal financial system. However, the countries including India could not reach the objective of complete financial inclusion due to the non-availability of the right technology and innovative financial products and services. Blockchain Technology emerged as a disruptor that drives and accelerates the financial inclusion movement through creating the digital identities, near real time payment settlements, reduced transactional, operational and administrative costs, developing trust among the customers, and ensuring access to financial services by everyone at anytime round the clock and round the year with the help of its features such as decentralization, irrevocability, tamperproof transactions, peer to peer network, encryption using cryptography, consensus and transaction specific rules. Future studies can be conducted on how does Blockchain Technology changes various sectors of finance such as capital market, insurance, and banking sector?

\section{REFERENCES}

1. Center for financial markets and policy. Blockchain and Financial Inclusion. Georgetown University, 2017. https://finpolicy.georgetown.edu/announcements/center-releases-white-paper-on-blockchain-and-financial-inclusion/\#

2. Reserve Bank of India (2018). https://rbidocs.rbi.org.in/rdocs/content/pdfs/NSFIREPORT100119.pdf

3. Manu Jose ," Financial Inclusion and Financial Literacy: A Study with Reference to Kannur Dt, Kerala “, BEST: International Journal of Humanities, Arts, Medicine and Sciences (BEST: IJHAMS), Vol. 2, Issue 10, pp. 27-32

4. The World Bank. (2017, March 5). Global Findex. Retrieved April 12, 2020, from Global Findex: https://globalfindex.worldbank.org/\#data_sec_foc

5. The World Bank. (2017, March 5). Global Findex. Retrieved April 12, 2020, from Global Findex: https://globalfindex.worldbank.org/\#data_sec_foc

6. Lopez, T., \& Winkler, A. (2018). The challenge of rural financial inclusion-evidence from microfinance. Applied Economics. 50(14), 1555-1577. https://doi.org/10.1080/00036846.2017.1368990

7. Lopez, T., \& Winkler, A. (2018). The challenge of rural financial inclusion-evidence from microfinance. Applied Economics. 50(14), 1555-1577. https://doi.org/10.1080/00036846.2017.1368990

8. Demirgüç-Kunt, A., Honohan, P., \& Beck, T. (2008). Finance for all? Policies and Pitfalls in Expanding Access. The World Bank.

9. “Das, Maitreyi Bordia; Mehta, Soumya Kapoor. (2012). Poverty and Social Exclusion in India: Overview. World Bank, Washington, DC. () World Bank. https://openknowledge.worldbank.org/handle/10986/26337 License: CC BY 3.0 IGO. 
10. Lopez, T., \& Winkler, A. (2018). The challenge of rural financial inclusion-evidence from microfinance. Applied Economics. 50(14), 1555-1577. https://doi.org/10.1080/00036846.2017.1368990

11. García, M. J. R., \& José, M. (2016). Can financial inclusion and financial stability go hand in hand? Economic Issues. 21(2), 81-103. https://ideas.repec.org/a/eis/articl/216garcia.html

12. Hernandez, K. Blockchain for Development-Hope or Hype? (2017). IDS Rapid Response Briefing. 17. https://opendocs.ids.ac.uk/opendocs/handle/20.500.12413/12945

13. Alka Singh, "Role of Technology in Financial Inclusion ", International Journal of Business and General Management (IJBGM), Vol. 6, Issue 5, pp. 1-6

14. Don Topscott and Alex Topscott. Blockchain Revolution: How the technology behind Bitcoin is changing money, business, and the world. 2nd Edition, Penguin Random House LLC, 2018. http://blockchain-revolution.com/

15. Reserve Bank of India,

https://rbidocs.rbi.org.in/rdocs/Bulletin/PDFs/03AR_11022020510886F328EB418FB8013FBB684BB5BC.PDF

16. The World Bank. Distributed Ledger Technology (DLT) and Blockchain. The World Bank, Washington, 2017. Available at http://documents.worldbank.org/ curated/en /177911513714062215/ pdf/122140-WP-PUBLIC-Distributed- LedgerTechnology-and-Blockchain- Fintech-Notes.pdf

17. Botton, N. Blochchain and Trade: Not a Fix for Brexit, but Could Revolutionise Global Value Chains (If Governments Let it), ECIPE Newsletter, 2018. http://ecipe.org/publications/blockchain-and-trade/?mc_cid=4cd309bff6\&mc_eid=f7c9b1f07b

18. McKinsey and Company. How Blockchain could change the world, 2016. https://www.mckinsey.com/industries/technologymedia-and-telecommunications/our-insights/how-blockchains-could-change-the-world

19. Infosys Limited. "Blockchain Adoption in Financial Services." Bangalore, 2019. https://www.infosys.com/industries/consumerpackage-goods/documents/blockchain-adoption-financial-services.pdf

20. Gaurav Lodha\& I.V Trivedi, “Nabard: A Financial Inclusion through Regional Rural Banks (Rrb's)”, IMPACT: International Journal of Research in Business Management (IMPACT: IJRBM), Vol. 3, Issue 10, pp. 77-82

21. Infosys Limited. "Blockchain Adoption in Financial Services." Bangalore, 2019. https://www.infosys.com/industries/consumerpackage-goods/documents/blockchain-adoption-financial-services.pdf

22. Infosys Limited. "Blockchain Adoption in Financial Services." Bangalore, 2019. https://www.infosys.com/industries/consumerpackage-goods/documents/blockchain-adoption-financial-services.pdf

23. World Economic Forum (2016), “The Future of Financial Infrastructure: An Ambitious Look at How Blockchain Can Reshape Financial Services", Future of Financial Services Series, August. Available at: http://www3.weforum.org/docs/WEF_The_ future_offinancial_infrastructure.pdf

24. NASSCOM Avasant. "NASSCOM Avasant India Blockchain Report" 2019. https://avasant.com/nasscom-avasant-indiablockchain-report-2019/

25. NASSCOM Avasant. "NASSCOM Avasant India Blockchain Report" 2019. https://avasant.com/nasscom-avasant-indiablockchain-report-2019/

26. NASSCOM Avasant. "NASSCOM Avasant India Blockchain Report" 2019. https://avasant.com/nasscom-avasant-indiablockchain-report-2019/ 
27. Muhsin J. Jeewg, Abdal-Kareem F.Hassan \& Jawad. K. Zeboon, "Experimental and Numerical Investigation of the Dynamic Characteristic of Laminated Composite Plate Hybrid with Stee “, International Journal of GeneralEngineering and Technology (IJGET), Vol. 3, Issue 1, pp. 27-36

28. The World Bank. (2017, March 5). Global Findex. Retrieved April 12, 2020, from Global Findex: https://globalfindex.worldbank.org/\#data_sec_foc

29. The World Bank. (2017, March 5). Global Findex. Retrieved April 12, 2020, from Global Findex: https://globalfindex.worldbank.org/\#data_sec_foc 

